[56] Lavermicocca, P., Valerio, F., Evidente, A., Lazzaroni, S., Corsetti, A., Gobbetti, M. (2000). Purification and Characterization of Novel Antifungal Compounds from the Sourdough Lactobacillus plantarum Strain 21B. Applied and Environmental Microbiology, 66 (9), 4084-4090. doi: https://doi.org/10.1128/aem.66.9.4084-4090.2000

[57] Lavermicocca, P., Valerio, F., Visconti, A. (2003). Antifungal Activity of Phenyllactic Acid against Molds Isolated from Bakery Products. Applied and Environmental Microbiology, 69 (1), 634-640. doi: https://doi.org/10.1128/aem.69.1.634-640.2003

[58] Dal Bello, F., Clarke, C. I., Ryan, L. A. M., Ulmer, H., Schober, T. J., Ström, K. et. al. (2007). Improvement of the quality and shelf life of wheat bread by fermentation with the antifungal strain Lactobacillus plantarum FST 1.7. Journal of Cereal Science, 45 (3), 309-318. doi: https://doi.org/10.1016/j.jcs.2006.09.004

[59] Bover-Cid, S., Holzapfel, W. H. (1999). Improved screening procedure for biogenic amine production by lactic acid bacteria. International Journal of Food Microbiology, 53 (1), 33-41. doi: https://oi.org/10.1016/s0168-1605(99)00152-x

[60] Sunita, S. (2019). Development of starter cultures for fermented functional and /or healthy vegetable and fruit drinks in Project: Development of Functional and Convenience Foods from Agri-horticultural Produce (No CRSCIARI2014023255201 7-18). IRC -I presentation (for official use only).

\title{
APPLICATION OF CO-BIOPROCESSING TECHNIQUES (ENZYMATIC HYDROLYSIS AND FERMANTATION) FOR IMPROVING THE NUTRITIONAL VALUE OF WHEAT BRAN AS FOOD FUNCTIONAL INGREDIENS
}

\author{
Leonid Kaprelyants ${ }^{1}$ \\ leonid@onaft.edu.ua \\ Liliia Pozhitkoval \\ pozhitkova@ukr.net \\ Mykola Buzhylov \\ buzhylovnic@ukr.net \\ ${ }^{1}$ Department of Biochemistry, Microbiology and Physiology of Nutrition \\ Odessa National Academy of Food Technologies \\ 112 Kanatna str., Odessa, Ukraine, 65039
}

\footnotetext{
Abstract

Last time the food industry pays the great attention to questions, connected with changing existing technologies for raising the efficacy of the raw materials complex processing and increasing the output of high-quality products and food ingredients with a minimal amount of waste. Cereal crops are the most reach source of functional ingredients and main component in the human food ration. The technological process of cereal crops processing at enterprises is closely connected with creating a great number of secondary raw material resources and its further utilization.

For confirming the efficacy of using secondary products of grain processing as cheap raw material resources of dietary fiber and physiologically functional ingredients, there is characterized the accessibility of their biotransformation that gives a possibility to get biologically active substances of different chemical nature with a wide spectrum of physiological effects.

Secondary products of cereal crops processing (bran) are multi-component substrates, formed of different histological layers of wheat grains after comminution, consisted of (external pericarp, internal pericarp, grain coat, hyaline and aleurone layer of a grain coat).

Wheat bran is rich in dietary fiber, nutritive and phytochemical substances, that is why, it is most often used for feeding animals. But for today there are important proofs of using it in the food industry.
} 
The development of new innovative technologies, modern achievements in microbiology and biotechnology have an important value for secondary products of grain processing, because they allow to conduct directed technological processes at the qualitatively new level that provides using soft regimes of vegetable raw materials processing, allowing to preserve natural biologically active substances and nutrients.

The modeling of the combined complex processing that includes enzymatic hydrolysis and fermentation by microorganisms improves technological, sensor and also nutritive and physiologically functional properties of wheat bran at the expanse of: bioavailability increase of phenol compounds, vitamins and minerals, assimilability of proteins and decrease of the content of anti-nutritive compounds.

Enzymatic preparations allow to use vegetable raw materials rationally, to intensify technological processes, in such a way increasing the output of biologically active substances and to widen the assortment of created products. The process of wheat bran formation results in increasing the nutritional value, enriching the biopolymeric complex with probiotic microorganisms and prebiotic substances.

Based on the structural peculiarities and multicomponent composition of wheat bran, presented and studied in the article, it has been established, that the use of the directed modification allows to get functional ingredients and products with set properties that influence the human health favorably. So, wheat bran must be used not only in agriculture as a cattle fodder, but also in the food industry.

Keywords: wheat bran, microstructure of wheat bran, fermentation, lactic acid bacteria, enzymatic hydrolyses, dietary fiber, bioactive compounds, antioxidant activity.

DOI: $10.21303 / 2504-5695.2019 .00992$

\section{Introduction}

Wheat is a grassy plant that is the second by prevalence and consumption after rice. The main direction of its use is bakery and macaroni production [1-3]. Wheat grains consist of a series of anatomic parts: embryo, endosperm, containing starch grains for providing energy at germination; thick layer of aleurone cells, encircling an endosperm; and pericarp. Bran fractions consist of a pericarp, hyaline and aleurone layers. In the total mass of wheat grains a bran fraction is (14-16\%), embryo (2-3\%) and endosperm (mainly starch): $81-84 \%$ [4]. The traditional technology of wheat grains processing is based on separating an endosperm from the bran and embryo layers. Cells of the aleurone layer together with other pericarp layers and embryos are eliminated with forming a bran fraction $[5,6]$.

The chemical composition of wheat bran is remarkable for the high content of not assimilated polysaccharides and their complexes (dietary fiber): cellulose, hemicelluloses, pectin substances and lignin (near 43-44\%). Dietary fiber favor the decrease of risks of several chronic diseases, such as cardiovascular ones (CVD), metabolic syndrome, diabetes 2 type and several types of cancer diseases [7-10]. Many countries of the world have dietary recommendations for consumption norms of dietary fiber. Today the Ministry of health protection of Ukraine has the accepted physiological norm of dietary fiber that is $15 \mathrm{~g}$ for $1000 \mathrm{kcal}$ of the food ration. The norm of dietary fiber is divided in soluble 2-6 $\mathrm{g}$ and insoluble $25-30 \mathrm{~g}$ for day. The medical consumption norm is no more $40-45 \mathrm{~g}$ for day, the maximal day dose must not exceed $60 \mathrm{~g}[11,12]$.

Alongside with dietary fiber, bran contains also bioactive compounds (or phytosubstances), such as alkylresorcinols, lignans, phenol acids, phytosterols, tocopherols, tocotrienols, folates $[13,14]$.

Fig. 1 schematically presents the location of the main food substances and phytocomponents of wheat grains, conventionally divided by anatomic layers [15-18].

The analysis of the wheat bran microstructure shows that they may be considered as a perfect raw material for developing optimized products and ingredients of the functional directionality [19-22].

Scientific studies, directed on revealing a possible connection between nutrition and degenerative human diseases started in the middle of the previous century. Health nutrition is provided by the presence of correspondent food products. Healthy products must contain enough and balanced quantities of different ingredients: proteins, lipids, carbohydrates, mineral substances, 
vitamins and other biologically active substances, manifesting the specific physiological activity, adding sensor and food properties of products.

The history of creating healthy food products, then named physiologically functional or shortly functional ones (PFP) started from 80 -ies of the previous century. For the first time the conception of PFP and the correspondent term were proposed in 1984 in Japan. In Europe and USA this conception found its wide spread in 1990-ies and still developing actively till today [23].

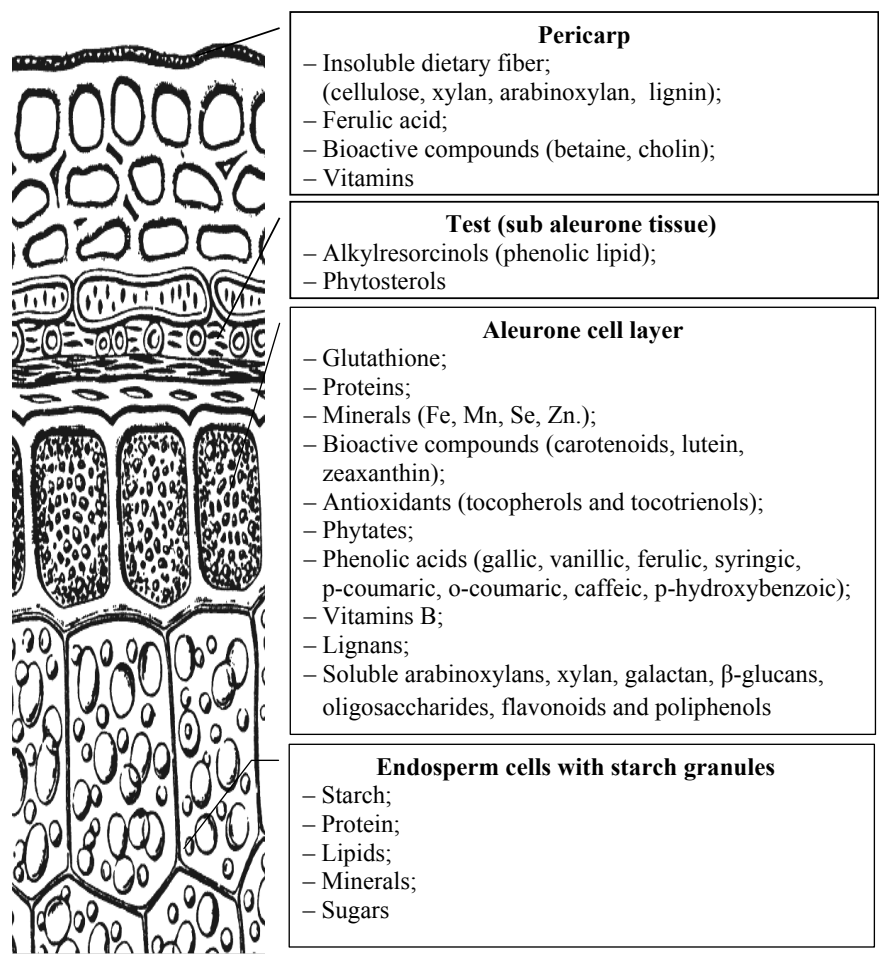

Fig. 1. Microstructure of wheat bran and the chemical composition of the individual layers

PFP are defined as products that, due to the presence of physiologically active components, provide advantages for health and pay an important role in decreasing or minimizing a risk of diseases, including prophylaxis and treatment of different ones [24].

Functional-physiological properties of wheat bran that allow to relate them to the category of functional products are conditioned mainly by the presence of biologically active substances in them: dietary fiber, phenol compounds of phytic acid, vitamins of B group, alkylresorcinols and other phytochemical substances $[25,26]$. They have a great potential for applying in the composition of food products.

The promising direction of increasing bran consumption is to create new biotechnological approaches of the complex raw material processing by biotransformation of the polymer complex of cellular walls, using enzymatic preparations, as the most effective way of getting functional ingredients and widening the market assortment of functional food products that may have an independent physiological effect on the human organism.

\section{Physiological effects of wheat bran and grains}

Bran fractions, obtained by dry comminution, are rich in cellulose, minerals, vitamins of B group, thiamine, folates-vitamin E and several phytochemical substances, exceptionally, antioxidants, such as phenol compounds. Nevertheless, the bioavailability of food substances of bran depends on processing type and conditions. Bran is used in production of brown and wholegrain flour, in such a way preserving several valuable food components that diminish at their elimination and refinement of white flour. The main physiological effects of wheat bran are presented on Fig. 2 [27-32]. 


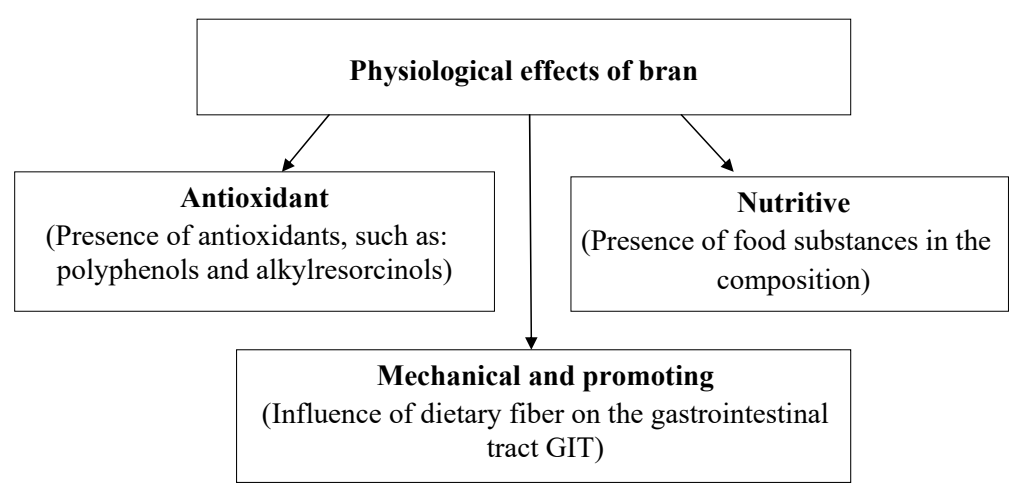

Fig. 2. Physiological effects of wheat bran

The base of bran is polymers of carbohydrate nature - cellulose, hemicelluloses, pectin substances, xylans, at the same time it contains starch, proteins and low-molecular organic substances. The chemical composition of bran varies depending on wheat variety, cultivation conditions and processing methods (bran separation). Table 1 presents main nutrients and biologically active compounds, found in wheat bran $[5,34,35]$.

The results of experimental studies testify to the positive influence of antioxidant phytochemical substances from a whole wheat grain. It is known, that antioxidants are presented in all bran fractions, where their content reaches $83 \%$ from the total amount of phenol substances in wheat grains. As a result, a bran fraction has a higher antioxidant activity than other ones, obtained at wheat grain milling [36-38].

Phytic acid is an organic compound, present in crops, usually as hexaphosphate myoninositol. It is concentrated in the external layer of a pericarp and covers the aleurone layer of a grain. $90 \%$ of phytic acid in a grain is in the aleurone layer and $10 \%$ in the embryo. So, an amount of phytic acid essentially varies in different fractions, eliminated at grain milling [39, 40].

Table 1

Chemical composition of wheat bran (\% abs. Dry substances)

\begin{tabular}{cccc}
\hline Parameters & Content & Parameters & Content \\
\hline Moisture & $12.5-13.1$ & Vitamins E, mg/g & $0.01-0.02$ \\
Protein & $13.1-13.8$ & $\mathrm{~B}_{1}, \mathrm{mg} / \mathrm{g}$ & $15.5-16.3$ \\
Lipids & $3.7-4.0$ & $\mathrm{~B}_{2}, \mathrm{mg} / \mathrm{g}$ & $12.2-13.0$ \\
Carbohydrates & $57.0-58.5$ & $\mathrm{~B}_{5}, \mathrm{mg} / \mathrm{g}$ & $12.2-12.7$ \\
Starch & $20.3-22.5$ & Flavonoids & $0.03-0.4$ \\
Hemicelluloses & $18.2-18.9$ & Alkylresorcinol & $0.29-0.32$ \\
Oligosaccharides & $3.7-4.0$ & Phytosterols & $0.15-0.17$ \\
Cellulose & $19.5-20.3$ & Phytic acid & $4.2-4.4$ \\
Lignin & $5.4-6.1$ & Ferulic acid, mcg/g & $100-220$ \\
Phenol acids & $1.1-1.6$ & Mineral substances & $5.1-5.7$ \\
Polyphenols & $1.1-1.2$ & Dietary fiber & $41.4-54.2$
\end{tabular}

Wheat contains near $1.13 \%$ of phytate. The content of phytic acid varies from 200 to $400 \mathrm{mg} / 100 \mathrm{~g}$ in refined flour and $600-1000 \mathrm{mg} / 100 \mathrm{~g}$ in wholegrain flour. Its content in wheat bran varies from 3116 to $5839 \mathrm{mg} / 100 \mathrm{~g}$ of dry weight. Most mineral substances are present in wheat bran as complexes with phytic acid [27, 41, 42].

A mature wheat grain has a high phytase activity that favors hydrolysis of phytates and obtaining of mineral substances, well assimilated at digestion. Nevertheless, phytates are considered as inassimilable substances for humans, because of their influence on the bioavailability of iron, 
magnesium, zinc and calcium. Although this mechanism has not been discovered, it is supposed that phytic acid creates a strong connection with mineral cations, creating phytate, forming mineral complexes that change their solubility [43-45].

Novel sources of dietary fiber, such as those, generated from by-products of food processing have received much attention recently. Such a by-product is wheat bran, which is generated during the milling process. It has predominantly been used for animal feed, however there is a currently strong argument for its use for human consumption as it is rich in dietary fiber, protein and phytichemicals $[46,47]$.

A diet, abundant in dietary fiber, has been shown to decrease the risk of obesity, type II diabetes and coronary heart disease. Wheat bran, which has a fiber content of about $50 \%$, is a suitable source of insoluble fiber for foods [48].

The content of dietary fiber (cellulose, hemicelluloses, pectin substances and lignin) in wheat bran of different wheat varieties, cultivated in the South of Ukraine, varies from 38.9 to $55.1 \mathrm{~g} / 100 \mathrm{~g}$, and include both soluble and insoluble forms of dietary fiber (Table 2) [49].

Table 2

Content of dietary fiber in wheat bran of different wheat varieties, cultivated in the South of Ukraine (g/100g)

\begin{tabular}{ccc}
\hline Total content & Insoluble & Soluble \\
\hline $41.4-54.2$ & $39.1-48.9$ & $2.4-5.2$ \\
$38.9-55.1$ & $33.7-49.7$ & $5.2-5.4$ \\
$40.5-52.6$ & $37.7-44.5$ & $2.7-8.1$
\end{tabular}

The content of cellulose in wholegrain flour varies from 11.6-12.7\%. One of most rich cellulose sources is non-starchy polysaccharides (NSP) of bran, near $46 \%$. Main NSPs of bran are arabinoxylans, cellulose and $\beta$-glucan, their content is $70 \%, 24 \%$ and $6 \%$ respectively. The mass share of soluble cellulose in wheat is essentially less, near $1 \%$, than in other crops, for example, its content in barley is $3-11 \%$, oat $-3-7 \%$ [50-52].

Bioprocessing of bran with microorganisms (yeast, lactobacteria fermentation) or/with cell wall degrading enzymes (xylanase, cellulase, pectinase) is known to increase the soluble part of dietary fiber and there are physiological functional and rheological properties [53-55].

\section{Wheat bran and its influence on the human health}

In the last years experimental studies contain more and more data about the positive influence of wheat bran on the prophylaxis of different diseases [56].

Due to their antioxidant properties, wheat bran can prevent or brake the formation of certain cancer tumors, to intensify the motor-secretory function of the intestine, to prevent constipations, to have a positive influence at hypokinetic disorders of the biliary system, to influence positively the prophylaxis of different diseases of the gastrointestinal tract, including the diverticular stomach disease and the irritated intestine syndrome, CVD [57-60].

The colon microflora has a deep influence on health. Intestinal flora components can be modified, using dietary means, such as the increase of prebiotics consumption.

Prebiotics are considered as indigestible food ingredients that positively influence the master's health, selectively stimulating the growth and/or activity of one or limited number of bacteria in the colon. There are more and more proofs, confirming the theory about the favorable influence of prebiotics on the intestine health and the decrease of the risk of colon cancer and CVD. Prebiotic components of dietary fiber in wheat bran (including $\beta$-glucans) can be fermented by the colon microflora, in which result physiological changes of a colon content take place that influence swelling, water-retaining capacity and viscosity [61-64].

Butyric acid is one of products of prebiotics fermentation, acknowledged as a fuel for coloncytes, it also favors normalization of feces $\mathrm{pH}$, influencing the colon function. Changes in the colon microflora after bran consumption and metabolic output (including free ferulic acid) increased [65]. 


\section{Fermentation biotechnology in wheat bran processing}

Cereal crops are one of main food sources in the human ration and many by-products are created in their production chain [66].

Secondary products of grain processing are a rich source of physiologically functional ingredients, which biotransformation gives a possibility to get biologically active substances of different chemical nature with the wide spectrum of physiological effects [67-70].

Just that is why the biocatalytic processing of traditional types of grain raw materials, such as bran, has an important value for the further complex use at developing and making new commercially competitive functional products and ingredients.

Biotechnology, namely the use of enzymatic preparations and fermentation, is an important direction in realizing this idea, allows to improve technological, sensor and especially nutritive and functional properties of bran [71].

As a result of the bioavailability increase of mineral and phenol substances, vitamins, assimilability of proteins and different nutritive substances of the complicated matrix of grain coats, it is possible to get new products and physiologically functional ingredients by biotransformation with the participation of hydrolytic enzymes and further fermentation by selected yeast cultures. The complex biotechnological approach to bran processing will allow to widen their use in food essentially $[72,73]$.

Fermented grain by-products intensify their food profile and can act as a carrier of correctors of the gastrointestinal tract GIT microbiota (prebiotics and probiotics) [74].

Biotechnological solutions of bran processing are the complex effect of biological objects on the complicated matrix of cellular walls of bran coats.

The components of bran cellular walls, such as cellulose, hemicelluloses, proteins and phenol compounds are connected with each other by both covalent and non-covalent connections, creating a structure of the complex matrix that is rather resistant to the effect of different physicalchemical and biological factors. Modifying effects of both exogenous and endogenous enzymes can partially change a structure of the complex of biopolymers of the bran matrix and increase their biological activity, bioavailability and nutritional value. Successive fermentation or one, associated with fermentolysis by sour-milk bacteria (and other ones) allows to get products with improved physiological and functional (healthy) properties [59, 75].

Wheat bran is multiple external wheat layers (external and internal pericarp, grain coat, nuclear epidermis), aleurone layer. Different types of bran milling (rough or usual bran, fine bran, thin or middle bran) can be divided, depending on particles size and endosperm content in them [5, 6, 29].

Most spread polysaccharides of the bran layers - arabinoxylans and $\beta$-glucans. Nevertheless, such bioactive compounds of bran as dietary fiber and phenol acids, forming a cellular wall, are little accessible, because of the low bioavailability at penetrating the human organism [72, 76].

The additional fractioning and comminution of bran with its further enzymatic processing and fermentation are directed on the partial destruction of the multi-component complex of biopolymers of the matrix of bran cellular walls and allow to raise the food potential, to give new physiological properties.

Main groups of microorganisms, most often used in the composition of probiotic products and medical preparations, are sour-milk bacteria $p$. Lactobacillus and ones of the actinomycete group $p$. Bifidobacterium. Just these representatives under normal optimal conditions form the main part of the constant human micrioflora and play the key physiological role in its functioning.

We offer the biotechnological processing of bran, including two stages:

1) hydrolytic splitting by enzymes (xylanase, endoglucanase, cellulase);

2) further fermentation of the forming product by microorganisms Lactobacilus acidophilus, Bifidobacterium bifidum.

Such biotechnological effect has an essential influence on the bran microstructure, causing the partial destruction of structural components of cellular walls, resulting first of all in the solubility increase of arabinoxylans (in more than 10 times, comparing with native bran), that is the content of soluble dietary fiber and formation of oligomers of them with polymerization degree 5-8 that are carbohydrate high-effective prebiotic substances [77]. 
The studies, conducted with certain fractions of wheat bran by their additional processing by amylolytic enzymes ( $\alpha$-amylase and glucoamylase), allowed to modify (destruct) the matrix structure deeper at the expanse of hydrolytic splitting of starch polysaccharide fractions. Destarched wheat bran had the essential sorption and water-absorbing capacity that created products of the complex character, positively influenced probiotic microorganisms, protecting from the GIT aggressive medium, and also prebiotic components as arabinoxylan oligosaccharides, in the further chain of biotechnological transformations $[49,77]$.

Alongside with dietary fiber, wheat bran are a rich source of protein and may be considered as a replacement of animal protein (more $18 \%$ ) in the food and fodder industry. The protein bioavailability is influenced by different factors, including the stratified structure of wheat bran. The last studies show that the bioprocessing of wheat bran raises the protein bioavailability at the expanse of releasing them from the structural matrix and increasing the solubility [54]. Due to the proteolytic activity of sour-milk bacteria and endogenous proteases, activated by the low $\mathrm{pH}$ value at fermentation, the wheat bran bioavailability increased. It is known, that the digestibility of proteins in vitro (pepsin+trypsin) increases by $35 \%$ in fermented bran $[69,78]$.

The processing by different biotechnological ways influences the release and transformation of wheat bran protein. Under acid conditions the protein solubility essentially increases, reaching its maximum at endogenous enzyme activation. Using enzymatic preparations of the directed effect and controlling the process of enzymatic hydrolysis, it is possible to get the maximal output of protein [73]. The results of this study discover new possibilities of biotechnology that increase the bioavailability of wheat bran proteins.

For releasing soluble proteins at dehydration of a cellular wall of wheat bran, there was applied hydrolysis of carbohydrates, and proteolytic enzymatic preparations were used. The study showed that enzymes with the exceptionally carbohydrate hydrolyzing activity increased the level of water-soluble pentosan and decreased the sugar content, but didn't increase the protein water-solubility and its release from cells of the aleurone layer [73]. Enzymes with the proteolytic activity essentially increased protein solubilization to $58.2 \%$ in 4 hours after the beginning of fermentation. The protein increase took place at the processing by protease (during 3 hours, at temperature $35{ }^{\circ} \mathrm{C}$ and enzyme specific activity 550 [nkat/g]), protein solubilization was $(>48 \%$ ), and content of amino nitrogen free $(<45 \mathrm{mg} / \mathrm{l})$. It has been established, that the protein intensive solubilization in the aleurone layer of wheat bran is possible at using exogenous enzymes with the proteolytic activity [79].

The use of microorganisms in fermentation of vegetable raw materials results in increasing the nutritional value, enrichment of the biopolymeric complex with probiotic microorganisms and prebiotic substances. For today there is a tendency of increasing the demand for food products, made by the natural way, without adding chemical supplements, nutritive and safe.

For producing multi-functional ingredients by fermentation of the medium on the grain base in the bakery industry, there were studied mixed cultures of sour-milk and propionic acid microorganisms and exopolysaccharides for the additional carbohydrate metabolism. Sour-milk bacteria produce lactate, and propionic acid ones metabolize lactate to acetate and propionate. The conducted screening of cultures of sour-milk and propionic acid bacteria demonstrated that the high potential was inherent to strains of L. plantarum SM39 microorganisms (with the high content of folate) $P$ freudenreichii DF16 and three strains of Weissella, producing organic acids for the anti-microbial effect; folate and vitamin $\mathrm{B}_{12}$ for nutrition; exopolysaccharides for improving the texture and storage term [80].

The optimized stages of two-stage fermentation with co-cultivation (3 days - aerobic and 4 days - anaerobic) increase the output of vitamins, exopolysaccharides and antimicrobial activity. The authors have established the optimal parameters, at which the maximal output and synchronously production of natural folate (5-formyl tetrahydrofolate acid), cyanocobalamin near $6.1 \mathrm{mg} / 1$ and near $20 \mathrm{~g} / 1$ of exopolysaccharides were observed. The antimicrobial effect of biologically active substances (added in dough at the equivalent propionate levels from 0.1 to $0.3 \%$ ) were demonstrated and studied in a test for baking bread, adding different spores of mould or bacilli. The high stability (near $60 \%$ ) of folate, acetate and propionate retention at baking was observed with mini- 
mal losses at storage; adding exopolysaccharides resulted in the improvement of the bread texture. Really, new polyfunctional biologically active ingredients, developed in this project, discover new possibilities for raising the value of natural bread and bakery products and for prolonging their storage life [81].

The special attention to classic propionic acid bacteria as to potential probiotics is conditioned by their properties. They are oriented on producing antibiotics and bifidogenous substances of different nature. There has been proved the antibiotic activity of propionic acid bacteria against gram positive and gram negative bacteria, yeast, fungal mycelium. Today it is considered, that polypeptides, activating proteases, are very similar by structure to peptides, separated from Lactobacillus lactis. Their gen is contained in plasmids and is characterized by the horizontal transfer. The antibiotic activity is inherent to Propionibacterium jenseniiSM11 and different strains of Lactobacillus paracasei subsp. paracasei to yeast, causing spoilage of sour-milk products [81]. The bifidogenous activity of propionic acid bacteria is conditioned by production of 1,4-hydroxy-2-naphthoic acid, 2-amino3-carboxy-1,4-naphthoquinone and several short chain fatty acids that are inhibitors of gram negative facultative and obligate anaerobes. Main producers of bifidogenous factors are Propionibacterium freudenreichii subsp. freudenreichii and P. freudenreichii subsp. Shermanii bacteria [82-84].

At revealing synthesis of bifidogenous factors of $P$. acidipropionici under aerobic conditions, there was studied the cultural liquid, obtained by cultivating propionic acid bacteria. For co-cultivation, cultures of sour-milk and propionic acid bacteria were selected for the additional metabolism on sugars. The study showed that new polyfunctional biologically active ingredients may be used for getting natural high-quality supplements with antifungal active propionate. It has been also established, that the use of L. acidophilus leaven results in releasing ingredients that may be used for producing high-quality supplements and active concentration of antifungal propionate [20].

At studying pripionic bacteria and factors, connected with food matrixes that influence synthesis of the vitamin $\mathrm{B}_{12}$, it has been established, that the mean output of the vitamin $\mathrm{B}_{12}$ in matrixes of cereal crops by $P$. shermanii was $2.5 \mathrm{mcg} / 100 \mathrm{~g}$. Propionic bacteria can produce the active vitamin $B_{12}$ in cereal culture models, at that fermentation of wheat bran may have an essential importance for enriching food products with the vitamin $\mathrm{B}_{12}$ [85].

The use of L. acidophilus leaven results in releasing bound phenolic acids (ferulic, hydroxycinnamic), that are a structural component of cellular walls of the aleurone layer of bran and are mainly etherified by arabinoxylans Fig. 3.

The release of ferulic acid allows to increase the content of free phenolic acids (by $80 \%$ ), and to raise the antioxidant activity of a product essentially [86, 87].

The influence of bioprocessing on the structure and chemical properties of wheat and rye bran in vitro and microbial (Lactobacillus acidophilus) release and conversion of phenolic acids of bran were studied. Wheat bran was bioprocessed with hydrolytic enzymes (Viscozyme L) and with $L$. acidophilus. The chemical composition of dietary fiber (DF), arabinoxylans (AX), protein, starch, fat, phenolic acids, ash, xylooligosaccharides (XOS), arabinoxylooligosaccharides (AXOS) and physiological properties of the fermented products of wheat and rye bran were analyzed. Co-bioprocessing of bran improve the technological and nutritional profile, thereby changing modification of carbohydrates and proteins. Fermentation is a tool to improve the nutritional profile of bran: releases proteins and bioactives from the cell wall bran matrix. The results suggest that bioprocessed wheat and rye bran are "stable" functional ingredients for food products that can be used to improve their nutritional and technological properties [77, 88].

It is known, that the bioavailability of mineral substances of bran strongly depends on the content of phytic acid that is considered as an antinutritive factor. At fermentation by sour-milk bacteria there is observed the increase of phytase activity, especially at using hydrolase enzymes for bioprocessing bran that favor the decrease of the phytic acid mass share.

The main parts of minerals in cereals are complexly bound to phytic acid as phytate, a phosphor-rich component, used by all cereal grains as mineral store. Phytate are insoluble at psychological $\mathrm{pH}$, and, therefore, minerals are unavailable for absorption in the human intestine. The reduction of phytate in bran by cutting off the phosphate groups causes an increased absorption of 
the minerals. The reduction of phytate can be achieved by enzymatic degradation during food processing activity of phytases from the cereals or by addition of phytase-active lactic acid bacteria or yeasts. The identification of high phytase-active microorganisms is necessary in order to find prominent candidates for the production of bran with high content of bioavailable minerals. High phytase-active yeasts and/or lactic acid bacteria, adapted in bran matrixes, might be a good choice for the modification bran. The high extracellular phytase activity was found in isolates of $S$. cerevisiae, followed by C. humilis and L. acidophilus [79, 89].

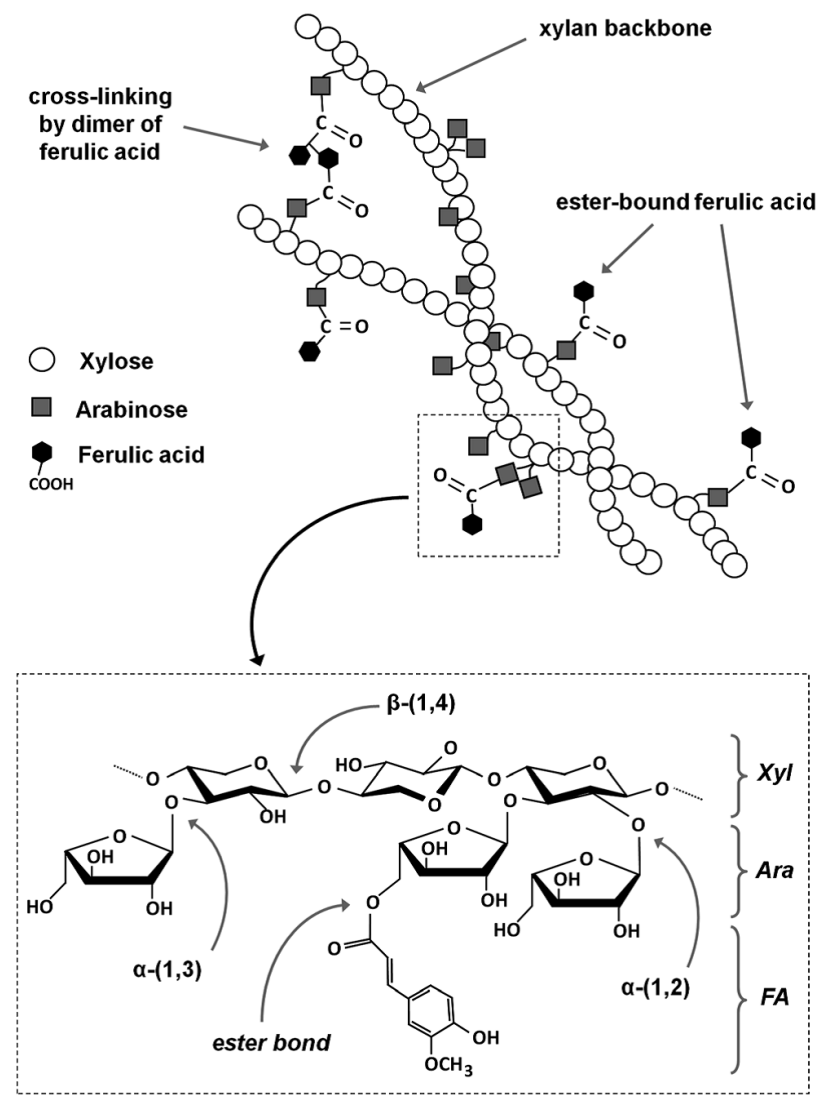

Fig. 3. Scheme of ferulic acid binding with arabinoxynan of the cellular wall of wheat bran

It is necessary to note, that the enzyme-fermentative biotechnology of wheat bran bioprocessing allows to get bioproducts (dietary supplements) with the complex carbohydrate composition of inassimilable dietary fiber of the double-oriented prebiotic effect: low-molecular (xyloarabinooligomers) and high-molecular polysaccharides (hemicelluloses). The schematic presentation of the biotechnological processes, taking place in wheat bran at obtaining functional food ingredients, is given on Fig. 4.

Prebiotic complex preparations of low- and high-molecular inassimilable food fiber can create a great potential in preventing and treating dysbioses, because at fermentation in the lower sections of the intestine, they are substrates for creating such short chain fatty acids, important for the human organism, as propionate and butyrate. The offered model of metabolic activity of high-molecular and low-molecular carbohydrate prebiotics is formed on creation of short chain fatty acids (SCFA) at their fermentation in GIT.

The series of works demonstrate that compositions of low-molecular and high-molecular carbohydrate prebiotics differ by healthy effects for GIT and for preventing a series of diseases [78, 90-92].

Carbohydrate complex prebiotics, fermented in the low section of the intestine, can change microbiome much more effectively, taking into account the fact that such fermentation is realized by sour-milk bacteria. 


\begin{tabular}{|c|c|c|c|c|}
\hline $\begin{array}{l}\text { Bioprocessing } \\
\text { employed }\end{array}$ & $\begin{array}{l}\text { Bran matrix } \\
\text { components }\end{array}$ & $\begin{array}{l}\text { Conversion } \\
\text { reaction }\end{array}$ & $\begin{array}{l}\text { Principle } \\
\text { products }\end{array}$ & Effect \\
\hline $\begin{array}{l}\text { Fermentolysis }+ \\
\text { Lactic acid } \\
\text { fermentation }\end{array}$ & $\begin{array}{l}\text { Phytochemicals } \\
\text { vitamins }\end{array}$ & $\begin{array}{l}\text { Hydrolysis, } \\
\text { deetherifi- } \\
\text { cation }\end{array}$ & $\begin{array}{l}\text { Phenolics } \\
\text { alkylreso- } \\
\text { rcinol, folate }\end{array}$ & $\begin{array}{l}\text { Higher phenols content, } \\
\text { fortification of vitamin } \\
\text { (folic acid) and } \\
\text { probiotics }\end{array}$ \\
\hline \multicolumn{5}{|c|}{2} \\
\hline $\begin{array}{c}\text { Fermentolysis } \\
\text { by exo-and endo } \\
\text { amylases }\end{array}$ & $\begin{array}{c}\text { Starch } \\
\text { polysaccharides }\end{array}$ & $\begin{array}{l}\text { Adjustable } \\
\text { hydrolysis }\end{array}$ & $\begin{array}{l}\text { Glucose, } \\
\text { maltose, } \\
\text { dextrins }\end{array}$ & $\begin{array}{c}\text { Increased digestibility } \\
\text { of carbohydrates }\end{array}$ \\
\hline \multicolumn{5}{|c|}{2} \\
\hline $\begin{array}{c}\text { Fermentation by } \\
\text { proteinases of } \\
\text { lactic acid } \\
\text { bacteria }\end{array}$ & Proteins & $\begin{array}{l}\text { Limited } \\
\text { proteolysis }\end{array}$ & $\begin{array}{c}\text { Amino acids, } \\
\text { peptides, } \\
\text { soluble, } \\
\text { proteins }\end{array}$ & $\begin{array}{l}\text { Bioactive peptides, } \\
\text { higher protein solubility } \\
\text { and increased } \\
\text { digestibility }\end{array}$ \\
\hline \multicolumn{5}{|c|}{ S } \\
\hline $\begin{array}{l}\text { Fermentolysis } \\
\text { by exo- } \\
\text { cellulose, } \\
\text { hemicelluloses } \\
\text { and pectinases }\end{array}$ & $\begin{array}{l}\text { Non-starch } \\
\text { polysaccharides } \\
\text { (cellulose, } \\
\text { hemicelluloses, } \\
\text { pectin's) }\end{array}$ & $\begin{array}{l}\text { Limited } \\
\text { hydrolysis }\end{array}$ & $\begin{array}{l}\text { Oligosacchar } \\
\text { ide-rides of } \\
\text { NSP, soluble } \\
\text { DF }\end{array}$ & $\begin{array}{c}\text { Higher DF solubility, } \\
\text { increased carbohydrate } \\
\text { prebiotics }\end{array}$ \\
\hline $\begin{array}{c}\text { Fermentation by } \\
\text { lactic acid and } \\
\text { propionic } \\
\text { bacteria }\end{array}$ & $\begin{array}{l}\text { Minerals, } \\
\text { vitamins }\end{array}$ & $\begin{array}{l}\text { Metabolic } \\
\text { synthesis of } \\
\text { vitamin }\end{array}$ & $\begin{array}{l}\text { Vitamin } \mathrm{B}_{12}, \\
\text { available } \\
\text { minerals }\end{array}$ & $\begin{array}{l}\text { Increased minerals } \\
\text { bioavailability }\end{array}$ \\
\hline
\end{tabular}

Fig. 4. Schematic representation of biotechnological processes by wheat bran for obtaining functional food ingredients

\section{Conclusions}

Wheat is the most important food component around the globe. Ukraine produces $25 \mathrm{ml}$ tons of wheat each year. It is commonly used in the refined form, excluding its outer husk waste, in the cereal industry, currently considered as valuable resources for conversion to value added products such as functional physiologically ingredients. Each year millions and tons of bran has been produced as a by-product of the wheat milling industry. Bran is one of the most important by-products of the cereal industry. Bran comprises the outer layers of grain, separated in the milling process during the production of flours. The high nutritional quality, especially the high content of dietary fiber, protein and phytochemicals, makes bran an interesting raw material for food products, but it is currently under-utilized as a food ingredient due to its technological and sensory challenges.

The high bioavailability of vitamins, minerals, protein, dietary fiber, low-molecular and high-molecular carbohydrate prebiotics and phenol compounds makes bran a unique and exclusive product in the food industry.

Treating-prophylactic properties of bran use the directed biomodification, giving a possibility to separate different biologically active supplements and ingredients with a great diapason of physiological effects that have the positive influence on the human health.

Today creation of new approaches to wheat bran processing for getting biologically active ingredients and functional products is urgent and needs scientifically substantiated solutions.

The study of different extraction methods showed that the use of rigid methods for destructing the combined complex of biopolymers of cellular walls (as a result of the effect of organic solvents and high temperatures) essentially decreases the biological value and also the output of purpose-oriented products (polyphenols, hydrolysates, hemicelluloses, carbohydrate-protein concentrates, dietary fiber).

Biocatalytic processing is the full use of secondary raw resources, at which the increase of the output of purpose-oriented products with determined and beforehand given functional properties takes place. 
Enzymatic and fermentation conversions have a principal role in increasing the efficacy of the production processes and utilization rate of the cereal raw material, and improving the sensory quality of the end product. Hydrolases are the most commonly used enzymes in industrial processes, and depending on the process, the aim is either complete or partial degradation of the cereal substrate. Solubilization, oxidation and degradation of cell wall components of bran by bioprocessing with hydrolytic enzymes such as xylanases, cellulases, pectinases, proteases has shown the potential as a means to improve the technological and nutritional properties of the bran in food applications.

The key factor of a successful use of wheat bran in food applications is the use of a cobioprocessing technology, including enzymatic treatment and fermentation with selected microorganisms. In the journey toward a more efficient food chain, biotechnological approaches for the valorization of cereal side streams can be considered a very valuable help. Wheat bran can serve as a potential nutritious and cheap raw material for production of food and could further improve the nutritional impact of the functional food.

Based on the studied data, we have developed the biotechnology for processing secondary products of grain processing, including hydrolytic splitting by enzymatic preparations (xylanase, endoglucase, cellulase) with further fermentation of the product by Lactobacilus acidophilus, Bifidobacterium bifidum microorganisms. Such biotechnological effect has the positive influence on the bran microstructure, causing partial destruction of cellular walls, resulting in the solubility increase of arabinoxylans that are carbohydrate high-effective prebiotic components. Such approach allows to get food products with treating and prophylactic properties.

This direction of studies potentially has the wide practical importance at making food products of the functional and prophylactic directionality in different branches on the food industry, for example, in the meat industry, milk production and bakery.

\section{References}

[1] Peña, R. J. (2002). Wheat for bread and other foods. Bread wheat improvement and production. Food and Agriculture Organization of the United Nations. Rome, 483-542.

[2] Dhiraj, B., Prabhasankar, P. (2013). Influence of Wheat-Milled Products and Their Additive Blends on Pasta Dough Rheological, Microstructure, and Product Quality Characteristics. International Journal of Food Science, 2013, 1-11. doi: https://doi.org/ $10.1155 / 2013 / 538070$

[3] Sette, S., D’Addezio, L., Piccinelli, R., Hopkins, S., Le Donne, C., Ferrari, M. et. al. (2015). Intakes of whole grain in an Italian sample of children, adolescents and adults. European Journal of Nutrition, 56 (2), 521-533. doi: https://oi.org/10.1007/s00394015-1097-5

[4] Šramková, Z., Gregová, E., Šturdík, E. (2009). Chemical composition and nutritional quality of wheat grain. Acta Chimica Slovaca, 2 (1), 115-138.

[5] Stevenson, L., Phillips, F., O'sullivan, K., Walton, J. (2012). Wheat bran: its composition and benefits to health, a European perspective. International Journal of Food Sciences and Nutrition, 63 (8), 1001-1013. doi: https://doi.org/10.3109/09637486. 2012.687366

[6] Brouns, F., Hemery, Y., Price, R., Anson, N. M. (2012). Wheat Aleurone: Separation, Composition, Health Aspects, and Potential Food Use. Critical Reviews in Food Science and Nutrition, 52 (6), 553-568. doi: https://doi.org/10.1080/10408398.201 1.589540

[7] Soliman, G. A. (2019). Dietary Fiber, Atherosclerosis, and Cardiovascular Disease. Nutrients, 11 (5), 1155. doi: https://doi.org/ 10.3390/nu11051155

[8] Shewry, P. R., Hey, S. J. (2015). The contribution of wheat to human diet and health. Food and Energy Security, 4 (3), $178-202$. doi: https://doi.org/10.1002/fes3.64

[9] Anderson, J. W., Baird, P., Davis Jr, R. H., Ferreri, S., Knudtson, M., Koraym, A. et. al. (2009). Health benefits of dietary fiber. Nutrition Reviews, 67 (4), 188-205. doi: https://oi.org/10.1111/j.1753-4887.2009.00189.x

[10] Jenkins, D. J. A., Kendall, C. W. C., Augustin, L. S. A., Martini, M. C., Axelsen, M., Faulkner, D. et. al. (2002). Effect of Wheat Bran on Glycemic Control and Risk Factors for Cardiovascular Disease in Type 2 Diabetes. Diabetes Care, 25 (9), $1522-1528$. doi: https://doi.org/10.2337/diacare.25.9.1522

[11] Kaprelyants, L. V., Petrosyants, A. P. (2011). Likuval'no-profilaktychni vlastyvosti kharchovykh produktiv ta osnovy diyetolohiyi. Odessa: Druk, 269. 
[12] Nakaz MOZ. Ukrainy «Pro zatverdzhennia Norm fiziolohichnykh potreb naselennia Ukrainy v osnovnykh kharchovykh rechovynakh ta enerhiyi. No. 272 vid 18.11.99. Available at: https://zakon2.rada.gov.ua/laws/show/z0834-99

[13] Bartłomiej, S., Justyna, R.-K., Ewa, N. (2012). Bioactive compounds in cereal grains - occurrence, structure, technological significance and nutritional benefits - a review. Food Science and Technology International, 18 (6), 559-568. doi: https://doi.org/ $10.1177 / 1082013211433079$

[14] Liukkonen, K.-H., Katina, K., Wilhelmsson, A., Myllymaki, O., Lampi, A.-M., Kariluoto, S. et. al. (2003). Process-induced changes on bioactive compounds in whole grain rye. Proceedings of the Nutrition Society, 62 (1), 117-122. doi: https://doi.org/ $10.1079 /$ pns2002218

[15] Kamal-Eldin, A., Lærke, H. N., Knudsen, K.-E. B., Lampi, A.-M., Piironen, V., Adlercreutz, H. et. al. (2009). Physical, microscopic and chemical characterisation of industrial rye and wheat brans from the Nordic countries. Food \& Nutrition Research, 53 (1), 1912. doi: https://doi.org/10.3402/fnr.v53i0.1912

[16] Antoine, C., Peyron, S., Mabille, F., Lapierre, C., Bouchet, B., Abecassis, J., Rouau, X. (2003). Individual Contribution of Grain Outer Layers and Their Cell Wall Structure to the Mechanical Properties of Wheat Bran. Journal of Agricultural and Food Chemistry, 51 (7), 2026-2033. doi: https://doi.org/10.1021/jf0261598

[17] Gartaula, G., Dhital, S., Netzel, G., Flanagan, B. M., Yakubov, G. E., Beahan, C. T. et. al. (2018). Quantitative structural organisation model for wheat endosperm cell walls: Cellulose as an important constituent. Carbohydrate Polymers, 196, 199-208. doi: https://doi.org/10.1016/j.carbpol.2018.05.041

[18] Bacic, A., Stone, B. (1981). Isolation and Ultrastructure of Aleurone Cell Walls From Wheat and Barley. Functional Plant Biology, 8 (5), 453. doi: https://doi.org/10.1071/pp9810453

[19] Prückler, M., Siebenhandl-Ehn, S., Apprich, S., Höltinger, S., Haas, C., Schmid, E., Kneifel, W. (2014). Wheat bran-based biorefinery 1: Composition of wheat bran and strategies of functionalization. LWT - Food Science and Technology, 56 (2), 211-221. doi: https://doi.org/10.1016/j.lwt.2013.12.004

[20] Kaprelyants, L., Yegorova, A., Trufkati, L., Pozhitkova, L. (2019). Functional foods: prospects in Ukraine. Food Science and Technology, 13 (2). doi: https://doi.org/10.15673/fst.v13i2.1382

[21] Onipe, O. O., Jideani, A. I. O., Beswa, D. (2015). Composition and functionality of wheat bran and its application in some cereal food products. International Journal of Food Science \& Technology, 50 (12), 2509-2518. doi: https://doi.org/10.1111/ijfs.12935

[22] Katina, K., Juvonen, R., Laitila, A., Flander, L., Nordlund, E., Kariluoto, S. et. al. (2012). Fermented Wheat Bran as a Functional Ingredient in Baking. Cereal Chemistry Journal, 89 (2), 126-134. doi: https://doi.org/10.1094/cchem-08-11-0106

[23] Kaprelyants, L. V., Iorgachova, K. H. (2003). Funktsional'ni produkty. Odessa: Druk, 312.

[24] Weststrate, J. A., van Poppel, G., Verschuren, P. M. (2002). Functional foods, trends and future. British Journal of Nutrition, 88 (S2), S233-S235. doi: https://doi.org/10.1079/bjn2002688

[25] Kaprelyants, L., Zhurlova, O. (2017). Technology of wheat and rye bran biotransformation into functional ingredients. International Food Research Journal, 24 (5), 1975-1979.

[26] Oseiko, M., Shevchyk, V., Romanovska, T. (2017). Functional products and preparations in the systemic concept of health. Ukrainian Food Journal, 6 (4), 661-673. doi: https://doi.org/10.24263/2304-974x-2017-6-4-7

[27] Adom, K. K., Sorrells, M. E., Liu, R. H. (2005). Phytochemicals and Antioxidant Activity of Milled Fractions of Different Wheat Varieties. Journal of Agricultural and Food Chemistry, 53 (6), 2297-2306. doi: https://doi.org/10.1021/jf048456d

[28] Antoine, C., Peyron, S., Lullien-Pellerin, V., Abecassis, J., Rouau, X. (2004). Wheat bran tissue fractionation using biochemical markers. Journal of Cereal Science, 39 (3), 387-393. doi: https://doi.org/10.1016/j.jcs.2004.02.001

[29] Zhu, K., Huang, S., Peng, W., Qian, H., Zhou, H. (2010). Effect of ultrafine grinding on hydration and antioxidant properties of wheat bran dietary fiber. Food Research International, 43 (4), 943-948. doi: https://doi.org/10.1016/j.foodres.2010.01.005

[30] Noort, M. W. J., van Haaster, D., Hemery, Y., Schols, H. A., Hamer, R. J. (2010). The effect of particle size of wheat bran fractions on bread quality - Evidence for fibre-protein interactions. Journal of Cereal Science, 52 (1), 59-64. doi: https://doi. org/10.1016/j.jcs.2010.03.003

[31] Zhou, K., Su, L., Yu, L. (Lucy). (2004). Phytochemicals and Antioxidant Properties in Wheat Bran. Journal of Agricultural and Food Chemistry, 52 (20), 6108-6114. doi: https://doi.org/10.1021/jf049214g

[32] Liangli, L. Y., Tsao, R., Shahidi, F. (Eds.) (2012). Cereals and pulses: nutraceutical properties and health benefits. John Wiley \& Sons, 328.

[33] Caprez, A., Arrigoni, E., Amadò, R., Neukom, H. (1986). Influence of different types of thermal treatment on the chemical composition and physical properties of wheat bran. Journal of Cereal Science, 4 (3), 233-239. doi: https://doi.org/10.1016/ s0733-5210(86)80025-x 
[34] Prückler, M., Siebenhandl-Ehn, S., Apprich, S., Höltinger, S., Haas, C., Schmid, E., Kneifel, W. (2014). Wheat bran-based biorefinery 1: Composition of wheat bran and strategies of functionalization. LWT - Food Science and Technology, 56 (2), 211-221. doi: https://doi.org/10.1016/j.lwt.2013.12.004

[35] Hossain, K., Ulven, C., Glover, K., Ghavami, F., Simsek, S., Alamri, M. S., Mergoum, M. (2013). Interdependence of Cultivar and Environment on Fiber Composition in Wheat Bran. Australian journal of crop science, 7 (4), 525-531.

[36] Onyeneho, S. N., Hettiarachchy, N. S. (1992). Antioxidant activity of durum wheat bran. Journal of Agricultural and Food Chemistry, 40 (9), 1496-1500. doi: https://doi.org/10.1021/jf00021a005

[37] Esposito, F., Arlotti, G., Maria Bonifati, A., Napolitano, A., Vitale, D., Fogliano, V. (2005). Antioxidant activity and dietary fibre in durum wheat bran by-products. Food Research International, 38 (10), 1167-1173. doi: https://doi.org/10.1016/ j.foodres.2005.05.002

[38] Andersson, A. A. M., Andersson, R., Piironen, V., Lampi, A.-M., Nyström, L., Boros, D. et. al. (2013). Contents of dietary fibre components and their relation to associated bioactive components in whole grain wheat samples from the HEALTHGRAIN diversity screen. Food Chemistry, 136 (3-4), 1243-1248. doi: https://doi.org/10.1016/j.foodchem.2012.09.074

[39] Weegels, P. (Eds.) (2009). Consumer Driven Cereal Innovation: Where Science Meets Industry. Elsevier.

[40] Wu, P., Tian, J.-C., Walker, C. E. (Chuck), Wang, F.-C. (2009). Determination of phytic acid in cereals - a brief review. International Journal of Food Science \& Technology, 44 (9), 1671-1676. doi: https://doi.org/10.1111/j.1365-2621.2009.01991.x

[41] Majzoobi, M., Pashangeh, S., Farahnaky, A., Eskandari, M. H., Jamalian, J. (2012). Effect of particle size reduction, hydrothermal and fermentation treatments on phytic acid content and some physicochemical properties of wheat bran. Journal of Food Science and Technology, 51 (10), 2755-2761. doi: https://doi.org/10.1007/s13197-012-0802-0

[42] Febles, C. I., Arias, A., Hardisson, A., Rodríguez-Alvarez, C., Sierra, A. (2002). Phytic Acid Level in Wheat Flours. Journal of Cereal Science, 36 (1), 19-23. doi: https://doi.org/10.1006/jcrs.2001.0441

[43] Oatway, L., Vasanthan, T., Helm, J. H. (2001). Phytic Acid. Food Reviews International, 17 (4), 419-431. doi: https://doi.org/ 10.1081/fri-100108531

[44] Bilgiçli, N., İbanoğlu, Ş. (2007). Effect of wheat germ and wheat bran on the fermentation activity, phytic acid content and colour of tarhana, a wheat flour-yoghurt mixture. Journal of Food Engineering, 78 (2), 681-686. doi: https://doi.org/10.1016/ j.jfoodeng.2005.11.012

[45] Nissar, J., Ahad, T., Naik, H. R., Hussain, S. Z. (2017). A review phytic acid: As antinutrient or nutraceutical. Journal of Pharmacognosy and Phytochemistry, 6 (6), 1554-1560.

[46] Schieber, A., Stintzing, F. C., Carle, R. (2001). By-products of plant food processing as a source of functional compounds - recent developments. Trends in Food Science \& Technology, 12 (11), 401-413. doi: https://doi.org/10.1016/s09242244(02)00012-2

[47] Javed, M. M., Zahoor, S., Shafaat, S., Mehmooda, I., Gul, A., Rasheed, H., Aftab, M. N. (2012). Wheat bran as a brown gold: Nutritious value and its biotechnological applications. African Journal of Microbiology Research, 6 (4), 724-733. Available at: http://citeseerx.ist.psu.edu/viewdoc/download?doi=10.1.1.1004.1499\&rep=rep1\&type=pdf

[48] Lattimer, J. M., Haub, M. D. (2010). Effects of Dietary Fiber and Its Components on Metabolic Health. Nutrients, 2 (12), 1266-1289. doi: https://doi.org/10.3390/nu2121266

[49] Buzhylov, M. G., Kaprelyants, L. V., Pozhitkova, L. G. (2019). Estimation of fractions of wheat cutting as biotechnological processing object. Scientific Works, 82 (2), 55-61. doi: https://doi.org/10.15673/swonaft.v82i2.1144

[50] Sidhu, J. S., Kabir, Y., Huffman, F. G. (2007). Functional Foods from Cereal Grains. International Journal of Food Properties, 10 (2), 231-244. doi: https://doi.org/10.1080/10942910601045289

[51] Fardet, A. (2010). New hypotheses for the health-protective mechanisms of whole-grain cereals: what is beyond fibre? Nutrition Research Reviews, 23(1), 65-134. doi: https://doi.org/10.1017/s0954422410000041

[52] Maheshwari, G., Sowrirajan, S., Joseph, B. (2017). Extraction and Isolation of $\beta$-Glucan from Grain Sources-A Review. Journal of Food Science, 82 (7), 1535-1545. doi: https://doi.org/10.1111/1750-3841.13765

[53] Coda, R., Katina, K., Rizzello, C. G. (2015). Bran bioprocessing for enhanced functional properties. Current Opinion in Food Science, 1, 50-55. doi: https://doi.org/10.1016/j.cofs.2014.11.007

[54] Arte, E., Rizzello, C. G., Verni, M., Nordlund, E., Katina, K., Coda, R. (2015). Impact of Enzymatic and Microbial Bioprocessing on Protein Modification and Nutritional Properties of Wheat Bran. Journal of Agricultural and Food Chemistry, 63 (39), 8685-8693. doi: https://doi.org/10.1021/acs.jafc.5b03495

[55] Verni, M., Rizzello, C. G., Coda, R. (2019). Fermentation Biotechnology Applied to Cereal Industry By-Products: Nutritional and Functional Insights. Frontiers in Nutrition, 6. doi: https://doi.org/10.3389/fnut.2019.00042

[56] Samaan, R. A. (2017). Dietary Fiber for the Prevention of Cardiovascular Disease: Fiber's Interaction between Gut Micoflora, Sugar Metabolism, Weight Control and Cardiovascular Health. Academic Press, 170. 
[57] Dreher, M. L. (2018). Dietary Patterns, Foods and Fiber in Irritable Bowel Syndrome and Diverticular Disease. Dietary Patterns and Whole Plant Foods in Aging and Disease, 165-192. doi: https://oi.org/10.1007/978-3-319-59180-3_6

[58] Masisi, K., Beta, T., Moghadasian, M. H. (2016). Antioxidant properties of diverse cereal grains: A review on in vitro and in vivo studies. Food Chemistry, 196, 90-97. doi: https://doi.org/10.1016/j.foodchem.2015.09.021

[59] Deroover, L., Tie, Y., Verspreet, J., Courtin, C. M., Verbeke, K. (2019). Modifying wheat bran to improve its health benefits. Critical Reviews in Food Science and Nutrition, 1-19. doi: https://doi.org/10.1080/10408398.2018.1558394

[60] Chakraborty, M., Budhwar, D. S. (2019). Critical Analysis of Wheat Bran as Therapeutic Source. International Journal of Trend in Scientific Research and Development, 3 (3), 296-303. doi: https://doi.org/10.31142/ijtsrd21755

[61] Costabile, A., Klinder, A., Fava, F., Napolitano, A., Fogliano, V., Leonard, C. et. al. (2007). Whole-grain wheat breakfast cereal has a prebiotic effect on the human gut microbiota: a double-blind, placebo-controlled, crossover study. British Journal of Nutrition, 99 (1), 110-120. doi: https://doi.org/10.1017/s0007114507793923

[62] Carlson, J. J., Eisenmann, J. C., Norman, G. J., Ortiz, K. A., Young, P. C. (2011). Dietary Fiber and Nutrient Density Are Inversely Associated with the Metabolic Syndrome in US Adolescents. Journal of the American Dietetic Association, 111 (11), 1688-1695. doi: https://doi.org/10.1016/j.jada.2011.08.008

[63] Gibson, G. R., Roberfroid, M. B. (1995). Dietary Modulation of the Human Colonic Microbiota: Introducing the Concept of Prebiotics. The Journal of Nutrition, 125 (6), 1401-1412. doi: https://doi.org/10.1093/jn/125.6.1401

[64] Joshi, D., Roy, S., Banerjee, S. (2018). Prebiotics. Natural Products and Drug Discovery, 507-523. doi: https://oi.org/10.1016/ b978-0-08-102081-4.00019-8

[65] Gunenc, A., Alswiti, C., Hosseinian, F. (2017). Wheat Bran Dietary Fiber: Promising Source of Prebiotics with Antioxidant Potential. Journal of Food Research, 6 (2), 1. doi: https://doi.org/10.5539/jfr.v6n2p1

[66] Luithui, Y., Baghya Nisha, R., Meera, M. S. (2018). Cereal by-products as an important functional ingredient: effect of processing. Journal of Food Science and Technology, 56 (1), 1-11. doi: https://doi.org/10.1007/s13197-018-3461-y

[67] Zhao, H.-M., Guo, X.-N., Zhu, K.-X. (2017). Impact of solid state fermentation on nutritional, physical and flavor properties of wheat bran. Food Chemistry, 217, 28-36. doi: https://doi.org/10.1016/j.foodchem.2016.08.062

[68] Coda, R., Rizzello, C. G., Curiel, J. A., Poutanen, K., Katina, K. (2014). Effect of bioprocessing and particle size on the nutritional properties of wheat bran fractions. Innovative Food Science \& Emerging Technologies, 25, 19-27. doi: https:/doi. org/10.1016/j.ifset.2013.11.012

[69] Nordlund, E., Katina, K., Aura, A.-M., Poutanen, K. (2013). Changes in bran structure by bioprocessing with enzymes and yeast modifies the in vitro digestibility and fermentability of bran protein and dietary fibre complex. Journal of Cereal Science, 58 (1), 200-208. doi: https://doi.org/10.1016/j.jcs.2013.05.006

[70] Sibakov, J., Lehtinen, P., Poutanen, K. (2013). Cereal brans as dietary fibre ingredients. Fibre-Rich and Wholegrain Foods, 170-192. doi: https://doi.org/10.1533/9780857095787.2.170

[71] Coda, R., Katina, K., Rizzello, C. G. (2015). Bran bioprocessing for enhanced functional properties. Current Opinion in Food Science, 1, 50-55. doi: https://doi.org/10.1016/j.cofs.2014.11.007

[72] Rezaei, S., Najafi, M. A., Haddadi, T. (2019). Effect of fermentation process, wheat bran size and replacement level on some characteristics of wheat bran, dough, and high-fiber Tafton bread. Journal of Cereal Science, 85, 56-61. doi: https://doi.org/ 10.1016/j.jcs.2018.11.019

[73] Arte, E., Katina, K., Holopainen-Mantila, U., Nordlund, E. (2016). Effect of Hydrolyzing Enzymes on Wheat Bran Cell Wall Integrity and Protein Solubility. Cereal Chemistry Journal, 93 (2), 162-171. doi: https://doi.org/10.1094/cchem-0315-0060-r

[74] Lamsal, B. P., Faubion, J. M. (2009). The Beneficial Use of Cereal and Cereal Components in Probiotic Foods. Food Reviews International, 25 (2), 103-114. doi: https://doi.org/10.1080/87559120802682573

[75] Zhang, H. W., Yang, M. D., Fan, X. F. (2011). Study on Modification of Dietary Fiber from Wheat Bran. Advanced Materials Research, 183-185, 1268-1272. doi: https://doi.org/10.4028/www.scientific.net/amr.183-185.1268

[76] Laddomada, B., Caretto, S., Mita, G. (2015). Wheat Bran Phenolic Acids: Bioavailability and Stability in Whole Wheat-Based Foods. Molecules, 20 (9), 15666-15685. doi: https://doi.org/10.3390/molecules200915666

[77] Kaprelyants, L. V., Zhurlova, E. D., \& Buzhilov, N. G. (2017)Prospects for the use of grain raw materials in the production of functoinal products. Grain Products and Mixed Fodder's, 18 (4), 18-26. doi: https://doi.org/10.15673/gpmf.v18i4.1191

[78] Wang, J., Sun, B., Cao, Y., Wang, C. (2010). In vitro fermentation of xylooligosaccharides from wheat bran insoluble dietary fiber by Bifidobacteria. Carbohydrate Polymers, 82 (2), 419-423. doi: https://doi.org/10.1016/j.carbpol.2010.04.082

[79] Zalán, Z., Hegyi, F., Szabó, E. E., Maczó, A., Baka, E., Du, M. et. al. (2015). Bran fermentation with lactobacillus strains to develop a functional ingredient for sourdough production. International Journal of Nutrition and Food Sciences, 4 (4), $409-419$. doi: https://doi.org/10.11648/j.ijnfs.20150404.11 
[80] Hugenschmidt, S., Miescher Schwenninger, S., Lacroix, C. (2010). No. PCT/CH2010/000006. Process for the preparation of a fermentation broth. Available at: https://patentscope.wipo.int/search/ru/detail.jsf?docId=WO2010078670

[81] Hugenschmidt, S., Schwenninger, S. M., Lacroix, C. (2011). Concurrent high production of natural folate and vitamin B12 using a co-culture process with Lactobacillus plantarum SM39 and Propionibacterium freudenreichii DF13. Process Biochemistry, 46 (5), 1063-1070. doi: https://doi.org/10.1016/j.procbio.2011.01.021

[82] Krupytska, L., Kaprelyants, L., Trufkti, L. (2017). Investigation of the antagonistic activity of secondary metabolites of propionic acid bacteria. Food Science and Technology, 11 (2). doi: https://doi.org/10.15673/fst.v11i2.508

[83] Krupytska, L., Kaprelyants, L., Trufkati, L., Velichko, T., Kirilov, V. (2018). Technology of Producing Symbiotic Biologically Active Additive. Food Science and Technology, 12 (2). doi: https://doi.org/10.15673/fst.v12i2.930

[84] Kaprelyants, L., Zhurlova, O., Shpyrko, T., Pozhitkova, L. (2017). Xylooligosaccharides from agricultural by-products: characterisation, production and physiological effects. Food Science and Technology, 11 (3). doi: https://doi.org/10.15673/fst.v11i3.606

[85] Chamlagain, B., Sugito, T. A., Deptula, P., Edelmann, M., Kariluoto, S., Varmanen, P., Piironen, V. (2018). In situ production of active vitamin B12 in cereal matrices using Propionibacterium freudenreichii. Food Science \& Nutrition, 6 (1), 67-76. doi: https://doi.org/10.1002/fsn3.528

[86] Boz, H. (2015). Ferulic acid in cereals - a review. Czech Journal of Food Sciences, 33 (1), 1-7. doi: https://doi.org/ 10.17221/401/2014-cjfs

[87] Deng, H., Jia, P., Jiang, J., Bai, Y., Fan, T.-P., Zheng, X., Cai, Y. (2019). Expression and characterisation of feruloyl esterases from Lactobacillus fermentum JN248 and release of ferulic acid from wheat bran. International Journal of Biological Macromolecules, 138, 272-277. doi: https://doi.org/10.1016/j.ijbiomac.2019.07.086

[88] Zhurlova, O., Kaprelyants, L. (2013). Fitokomponenti zernovogo siriya: stroenie, svoystva, primenenie. Harchova nauka i tehnologiya, 4, 3-7.

[89] Guo, J., Bian, Y.-Y., Zhu, K.-X., Guo, X.-N., Peng, W., Zhou, H.-M. (2015). Activation of Endogenous Phytase and Degradation of Phytate in Wheat Bran. Journal of Agricultural and Food Chemistry, 63 (4), 1082-1087. doi: https://doi.org/10.1021/jf504319t

[90] Nuobariene, L., Hansen, A.. S., Arneborg, N. (2012). Isolation and identification of phytase-active yeasts from sourdoughs. LWT - Food Science and Technology, 48 (2), 190-196. doi: https://doi.org/10.1016/j.lwt.2012.03.011

[91] McKay, A. M. (1992). Hydrolysis of vicine and convicine from fababeans by microbial $\beta$-glucosidase enzymes. Journal of Applied Bacteriology, 72 (6), 475-478. doi: https://doi.org/10.1111/j.1365-2672.1992.tb01861.x

[92] Lu, Z. X., Walker, K. Z., Muir, J. G., Mascara, T., O’Dea, K. (2000). Arabinoxylan fiber, a byproduct of wheat flour processing, reduces the postprandial glucose response in normoglycemic subjects. The American Journal of Clinical Nutrition, 71 (5), 1123-1128. doi: https://doi.org/10.1093/ajen/71.5.1123 